\title{
PENGARUH MEDIA TEBAK GAMBAR DAN TALKING STICK TERHADAP MOTIVASI BELAJAR SISWA
}

\author{
Eko Puji Dianawati \\ SMK Negeri 1 Nanggulan \\ diewabid@gmail.com
}

\begin{abstract}
Intisari
Media tebak gambar dan talking stick dapat mendorong pemahaman siswa terhadap materi pelajaran dan melatih disiplin dalam belajar, membangun kerjasama tim dalam kelompok, melatih siswa bertanggung jawab, memotivasi siswa berpendapat dengan santun dan percaya diri dalam berkomunikasi untuk meningkatkan kemampuan soft skills, serta mampu mengaplikasikan ilmu dalam kehidupan sehari-hari. Motivasi belajar yang tinggi mampu meningkatkan prestasi belajar.
\end{abstract}

Kata kunci: media, tebak gambar, talking stick, motivasi belajar

\section{PENDAHULUAN}

Salah satu tujuan Sekolah Menengah Kejuruan (SMK) adalah mencetak lulusan yang siap bekerja sesuai bidang keilmuannya, mampu menyesuaikan diri dengan perkembangan Iptek, serta mengembangkan diri dan karier di tempat kerja. BSNP (2006: 17) menyatakan SMK merupakan pendidikan kejuruan yang bertujuan meningkatkan kecerdasan, pengetahuan, kepribadian, akhlak mulia, serta keterampilan siswa untuk hidup mandiri dan mengikuti pendidikan lebih lanjut sesuai dengan program kejuruannya. Untuk mewujudkan itu, mereka harus memiliki stamina yang tinggi, menguasai bidang keahlian dan teknologi, memiliki etos kerja yang tinggi, mampu berkomunikasi, dan memiliki kemampuan mengembangkan diri.

Siswa SMK yang menempuh pendidikan vokasi dikatakan berkompeten jika secara keilmuan memahami, secara sikap matang dalam disiplin kerja, dan berkompeten dalam praktek. Mengingat masa depan akan dikuasai oleh orang-orang kreatif ("manusia otak kanan”), 
dengan seperangkat kepekaan terkait dengan aspek design, story, symphony, empathy, play, and meaning (Dewi, 2008: 1).

Ditinjau dari keberhasilan lulusan, lulusan SMK diharapkan: (1) bekerja sesuai bidang keahliannya; (2) tenggang waktu lulusan mendapatkan kerja setelah lulus maksimal satu tahun; (3) keterserapan lulusan dalam periode 2 tahun setelah lulus minimal 75\%; (4) jumlah lulusan yang mampu menciptakan lapangan kerja 5\% (Depdiknas, 2003: 3).

Siswa SMK tampak lebih bekerja dengan tenaga fisik (skills) dan malas berpikir menggunakan logika. Hal tersebut terjadi pada siswa SMK (Negeri 1 Nanggulan). Pada mapel praktek siswa cenderung senang melakukan, tetapi esensi materi praktek tidak diimbangi dengan teori. Indikasinya tampak pada nilai ulangan yang tidak mencapai kkm. Bahkan, kurang kreatif.

Pada saat praktikum pemupukan, siswa tidak memahami dosis pupuk, sehingga guru harus mengulang materi. Prosedur praktek atau observasi lapangan kurang dipahami, bahkan keselamatan dan kesehatan kerja (K-3) selama praktek tidak diindahkan. Hal tersebut menghambat proses pembelajaran praktek dan tuntutan lulusan SMK yang terampil dan kompeten. Tuntutan agar lulusan SMK penuh inovasi pun sulit tercapai.

Kurikulum 2013 menuntut siswa aktif, mandiri, dan inovatif. Kendalanya, motivasi siswa kurang dalam literasi atau membaca. Untuk kegiatan pembelajaran siswa aktif, guru hanya berperan mengaktifkannya dengan memberikan keleluasaan siswa belajar menemukan melalui metode browsing materi, namun keantusiasan siswa rendah. Itu terlihat dari target pencapaian materi yang kurang maksimal dan sebagian siswa melanggar tatacara browsing dengan menyalahgunakannya untuk bermain games atau bermain sosmed. Penerapan metode diskusi presentasi yang bertujuan membangun kemampuan kognitive dengan belajar menemukan, kemampuan psikomotorik untuk meningkatkan hard skills, serta kemampuan afektive dengan membangun kerjasama tim dalam kelompok, berpendapat dengan santun untuk meningkatkan 
kemampuan soft skills-nya, itu pun tidak berjalan dengan optimal, bahkan hanya membuang waktu karena rendahnya motivasi belajar secara mandiri.

Siswa SMK rata-rata berumur 15-19 tahun, mereka belum stabil kepribadian dan intelektualnya. Belajar jika ada ulangan harian, belajar masih disuruh, kuis dalam setiap pembelajaran hasilnya belum maksimal, pengumpulan tugas harus diingatkan, mengerjakan tugas hanya mencontek teman, pembelajaran dengan diktat agar siswa lebih siap dalam menerima mapel produktif, ternyata tidak dipelajari, pembelajaran dengan metode demonstrasi dan tanya jawab ternyata belum efektif.

Kemandirian siswa, asa ingin tahu, dan motivasi siswa dalam pembelajaran rendah. Untuk itu, guru sebagai motivator, fasilitator, mediator, demonstrator, pengelola kelas, dan model dalam pembelajaran cukup dibutuhkan. Maka, penulis mencoba menggunakan media "Tebak Gambar dan Talking Stick" (TGTS) sebagai media belajar yang dipadukan dengan permainan atau games, dengan harapan siswa tertarik untuk bermain, mampu merangsang daya ingat untuk memahami materi yang divisualisasikan melalui gambar (fotografi, simbol, lambang, kode). Materi K3 di laboratorium yang penuh dengan simbol keselamatan kerja yang harus diimplementasikan selama praktek, atau materi identifikasi hama dan penyakit di lahan budidaya yang sulit dipahami siswa, karena tidak ditemukannya hama maupun penyakit saat materi diajarkan, maka gambar fotografi dapat memvisualisasikan materi itu, sehingga mudah dipahami.

Tujuan penggunaan media TGTS adalah mendorong pemahaman siswa terhadap materi pelajaran dan melatih untuk berdisiplin dalam belajar, membangun kerjasama tim, melatih bertanggung jawab, memotivasi berpendapat dengan santun dan percaya diri dalam berkomunikasi (meningkatkan kemampuan soft skills), serta mampu mengaplikasikan ilmu dalam kehidupan sehari-hari. Motivasi belajar yang tinggi diharapkan mampu meningkatkan prestasi belajar siswa. 


\section{PEMBAHASAN}

\section{Motivasi Belajar Siswa}

Menjadi guru merupakan pekerjaan yang menuntut pembaharuan di setiap harinya. Pembaharuan tersebut tak hanya berdasarkan instrumen dalam pengajaran, namun dituntut untuk cerdas pula mengomparasikan instrumen pengajaran dengan wawasan yang dimilikinya. Bagi mereka yang memang memiliki passion sebagai guru, tentu akan cerdik dan selalu mencari teknik terbaik yang bisa diaplikasikan kepada para muridnya (http://www.psikoma.com/mengenal-teknik-mengajar-guru-masa-kini/html diakses pada 25 Agustus 2017)

Guru dituntut lebih kreatif dalam mengemas pembelajaran, memiliki jiwa yang menyenangkan, dari membangun komunikasi yang baik sampai memahami perkembangan dan karakter siswa. Guru berperan sebagai teaching motivating, yaitu mengajar sambil meningkatkan gairah belajar dan rasa ingin tahu siswa, dengan strategi pokok attention yang berkaitan dengan pemeliharaan terhadap minat, keingintahuan, dan perhatian.

Motif tidak dapat diamati secara langsung tetapi dapat diinterpretasikan dalam tingkah laku, berupa rangsangan, dorongan, atau pembangkit tenaga munculnya suatu tingkah laku tertentu (Isbandi, 1994: 154). Menurut Sardiman (2007: 75) motivasi adalah serangkaian usaha untuk menyediakan kondisi tertentu, sehingga seseorang mau dan ingin melakukan sesuatu, dan bila tidak suka, akan berusaha untuk meniadakan atau mengelakkan perasaan tidak suka itu. Motivasi adalah kekuatan, dari dalam maupun dari luar, yang mendorong seseorang untuk melakukan sesuatu agar mencapai tujuan.

Penggolongan atas terbentuknya motif dibedakan atas dua macam, yang menurut Hamzah (2008: 4), yaitu: (1) motif bawaan, sudah ada sejak dilahirkan, misalnya makan, minum, dan kebutuhan biologis; (2) motif yang dipelajari, misalnya dorongan untuk belajar ilmu maupun karena kedudukan atau jabatan. 
Motivasi dibedakan menjadi dua, yaitu motivasi intrinsik dan motivasi ekstrinsik (Hamzah, 2008: 4). Motivasi intrinsik timbul dengan tidak memerlukan rangsangan dari luar. Motivasi ekstrinsik timbul karena adanya rangsangan dari luar individu (adanya ajakan, suruhan atau paksaan dari orang lain). Motivasi intrinsik umumnya lebih kuat daripada motivasi ekstrinsik. Oleh karena itu, pendidikan sebaiknya berusaha menimbulkan motivasi intrinsik dengan menumbuhkan dan mengembangkan minat atau keingintahuan (curiosity) siswa terhadap mata pelajaran. Motivasi ditandai oleh timbulnya perasaan (affective arousal).

Beberapa cara untuk meningkatkan motivasi belajar, seperti diungkapkan Hamzah (2008: 34-37), yaitu: (1) menggunakan simulasi dan permainan. Simulasi merupakan upaya untuk menerapkan sesuatu yang sedang dipelajari melalui tindakan langsung; (2) mengembangkan persaingan dengan diri sendiri (ego-involvement), menumbuhkan kesadaran kepada siswa agar merasakan pentingnya tugas yang harus dilakukannya sendiri dan menerimanya sebagai tantangan sehingga bekerja keras; (3) memberitahukan hasil belajar yang telah dicapai. (4) pernyataan penghargaan secara verbal atau pujian, bentuk reinforcement yang positif dan memberikan motivasi yang baik bagi siswa; (5) hukuman yang mendidik (bentuk reinforcement negatif).

\section{Proses Belajar Siswa SMK}

Belajar diartikan sebagai proses perubahan perilaku sebagai akibat dari pengalaman dan latihan (Wina, 2011: 112). Teori belajar Thorndike dalam Eko (2012: 6), ada tiga hukum belajar yang berdampak pada keberhasilan belajar siswa; (1) Law of readiness, kesiapan untuk berbuat dapat memperlancar hubungan antara stimulus dan respons, (2) Law of exercise, dengan adanya ulangan-ulangan yang selalu dikerjakan, hubungan antara stimulus dan respons menjadi lancar, (3) Law of effect, hubungan antara stimulus dan respon menjadi lebih baik jika dapat menimbulkan hal-hal yang menyenangkan. 
Belajar adalah proses kegiatan individu yang menimbulkan perubahan, baik perubahan pengetahuan, kecakapan, kebiasaan, kemampuan, pengertian, maupun minat. Hubungan antara stimulus dan respons menjadi lebih baik jika menghasilkan hal-hal yang menyenangkan, dan berkesan.

Sebagai fasilitator utama, guru berperan membuat menu harian dalam sajian yang segar, menarik, tidak membosankan. Penyajian yang selalu baru dan bervariasi menjadi faktor untuk menentukan hasil proses pembelajaran. Memperbanyak diskusi dengan siswa, pda akhir akhir pelajaran dilakukan proses refleksi dan umpan balik.

Guru harus paham karakter siswa. Pembelajaran yang menyenangkan dapat memberikan efek luar biasa terhadap kuatnya otak dalm mempertahankan pengetahuan (knowledge) (Eko, 2012: 7). Guru harus mampu menerapkan transfer ilmu dengan cara Scanning \& Levelling, yaitu belajar dengan memahami dan menyesuaikan tingkat kecerdasan tiap siswa. Juga, harus mampu menerapkan kemampuan active interaction, yaitu mengajar sambil aktif berinteraksi dengan siswa. Dengan begitu, kedekatan dan ikatan emosional antara siswa dan guru akan terjalin baik (http://www.psikoma.com/mengenal-teknik-mengajar-gurumasa-kini/html. diambil pada 25 Agustus 2017).

Guru sebaiknya mengajar secara horizontal, yakni menempatkan diri sejajar dengan siswa, sehingga memberikan dorongan siswa untuk lebih santai dan lebih menikmati kebersamaannya dengan guru. Jika kelas sudah santai dan dinikmati, maka pelajaran mudah diberikan.

\section{Penggunaan Media TGTS}

Media gambar adalah media visual, tidak mengandung unsur suara (Wina, 2011: 172), segala sesutu yang diwujudkan secara visual dalam bentuk dua dimensi, seperti lukisan atau gambar, potret atau foto, slide, film, strip, projektor, dan grafik (Arsyad, 2002: 8). 
Salah satu manfaat penggunaan media adalah mempertinggi proses belajar siswa. Argumentasinya, (1) pembelajaran akan lebih menarik; (2) materi pelajaran akan lebih jelas maknanya; (3) metode mengajar lebih bervariasi, (4) siswa lebih banyak melakukan kegiatan belajar (Nana, 2005: 2).

Dalam proses pembelajaran keberadaan media gambar sangat penting karena memotivasi siswa selalu belajar memahami materi yang awalnya sulit dipahami. Karena dipelajari dengan menyenangkan dan menarik, materi mudah dipahami. Media TGTS merupakan bentuk media pembelajaran yang tergolong games (permaian). Games biasa berfungsi sebagai warming up, penghilang kejenuhan untuk materi yang melelahkan, maupun mendukung siswa lebih aktif dan memberi respons (Eko, 2012: 13).

Jika guru menyenangkan, siswa pun mudah menerima pelajaran. Bahkan, menurut Eko (2012: 15) ada suatu rumus $\mathbf{C G}+\mathbf{C P}=\mathbf{S B p} \mathbf{P}$ yang berarti jika siswa Cinta $\mathbf{G u r u}$ Plus $\mathbf{C i n t a}$ Pelajaran, maka akan Semangat Belajar, semangat belajar akan mengantarkan sukses meraih Prestasi.

Metode pembelajaran kooperatif dengan media TGTS merupakan pengembangan metode diskusi presentasi yang diperkaya dengan permainan media Tebak Gambar (TG), berupa lembar kegiatan yang dibagikan kepada siswa dalam bentuk gambar di halaman depan dan di bagian belakang gambar adalah keterangannya. Sebagai materi yang dipelajari bersama yang nantinya akan dipresentasikan, terjadilah transfer ilmu. Terjadinya sharing materi dengan metode tanya jawab, diharapkan siswa aktif belajar bersama.

Teknis pelaksanaan media Talking Stick (TS) dikenal dengan permainan tongkat. Dalam panduan materi sosialisasi KTSP (diselenggarakan oleh Dinas Pendidikan Nasional 2006): (1) guru menyiapkan tongkat; (2) guru menyampaikan materi pokok (media $T G$ ) dengan memberi kesempatan siswa mendiskusikan materi di belakang gambar bersama kelompoknya; (3) siswa mempresentasikan dan mentransfer materi dengan teknik tanya jawab; (4) guru mengacak 
media $T G$ dan mengambil tongkat; (5) untuk merefleksi materi dari kegiatan belajar bersama, siswa menyanyikan satu lagu yang sedang hits sambil mengedarkan tongkat, setelah lagu selesai tongkat akan berhenti kepada siswa; (6) siswa yang mendapat tongkat menjelaskan media $T G$ yang ditunjukkan guru; (7) jika siswa tersebut tidak mampu menjawab mendapatkan sanksi sesuai kesepakatan awal dan berhak memberikan kesempatan kepada siswa lain. Meskipun dibantu teman, siswa pemegang tongkat harus menjelaskan kembali materi dalam media $T G$ yang diterimanya tadi; (8) secara estafet tongkat berpindah ke tangan siswa lain secara bergiliran, demikian seterusnya, hingga seluruh siswa mendapat bagian; dan (9) guru memberikan poin pada setiap jawaban.

Media TGTS ini diterapkan sebagai refleksi dalam pembelajaran untuk mengukur daya serap atau tingkat pemahaman siswa terhadap materi pelajaran. Dengan penggunaan media tersebut secara otomatis memotivasi siswa untuk selalu belajar dan mengubah kebiasaan belajarnya. Kebiasaan positif itu akan berujung meningkatnya prestasi belajar. Metode ini dapat digunakan oleh antarsiswa dalam suatu kelompok. Sehingga, secara tidak langsung terjalin kerjasama dan rasa tanggung jawab.

\section{Contoh media Tebak Gambar}

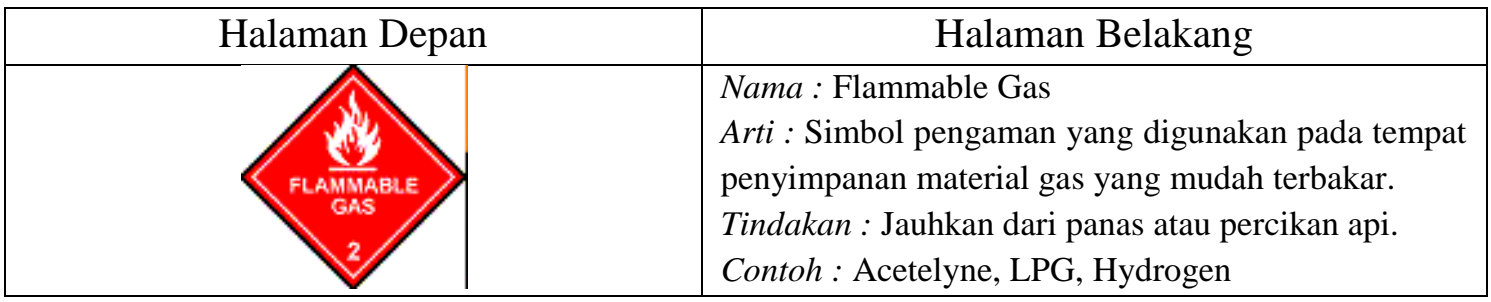

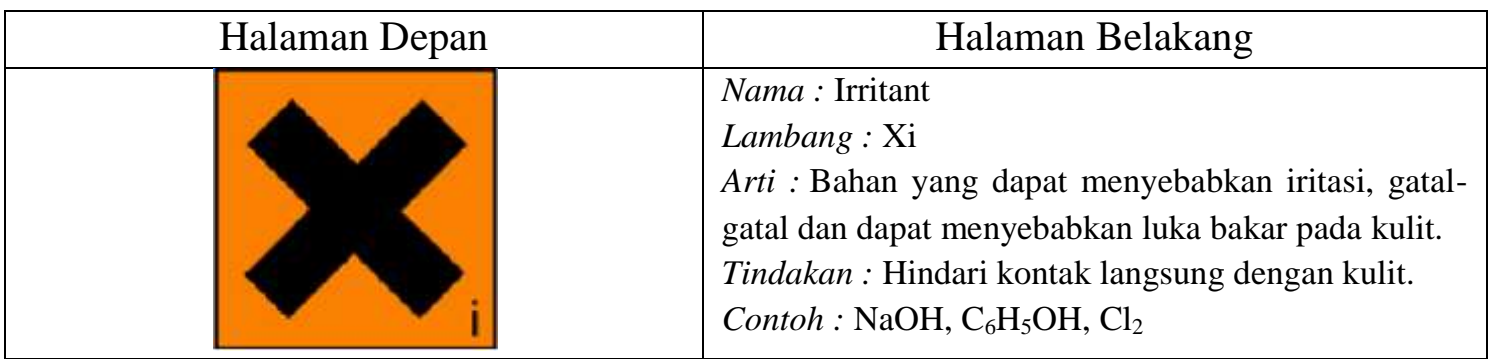




\section{SIMPULAN}

Kesiapan seseorang memasuki dunia kerja melibatkan tiga faktor: (1) fisiologis (kematangan usia, kondisi fisik, organ-organ tubuh); (2) pengalaman (pengalaman belajar atau bekerja, kemampuan pengetahuan dan keterampilan, hard skills); dan (3) psikologis (keadaan mental, emosi, dan social, kemampuan soft skills).

Pemilihan media yang tepat akan mewujudkan pembelajaran yang menarik, menyenangkan, dan membangun minat siswa untuk aktif. Tantangan guru adalah membuat siswa yang tidak bergairah belajar menjadi termotivasi.

Mengajar menggunakan bantuan media TGTS merupakan salah satu ikhtiar guru berinovasi dalam pembelajaran. Dengan media games, siswa menjadi lebih tertarik dan tidak bosan, sebagai pencair suasana (ice breaker), pemberi kekuatan (energizer) sebelum materi utama, membangkitkan emosi dan gairah belajar, memberi kesan menyenangkan, mencerahkan kejenuhan, menanamkan materi pelajaran lebih lama dalam ingatan siswa, dan memberikan catatan pada pikiran siswa. Dengan games jelas sekali suasana kelas menjadi lebih hidup, ceria, bersemangat, siswa semakin percaya diri, dan aktif dalam kegiatan pembelajaran. Kelebihan media TGTS adalah mendorong pemahaman siswa terhadap materi pelajaran, berani mengemukakan pendapat (Soft Skills), menerapkan ilmu dalam kehidupan sehari-hari, dan melatih disiplin belajar.

\section{DAFTAR PUSTAKA}

Adi, Isbandi Rukminto. (1994) Psikologi, Pekerjaan Sosial, dan Ilmu Kesejahteraan Sosial; Dasar-Dasar Pemikiran. Jakarta: Grafindo Persada

Arsyad, A. (2002) Media Pembelajaran. Jakarta: PT Raja Grafindo Persada.

Badan Standar Nasional Pendidikan (BNSP). (2006) Standar Isi. Jakarta: Departemen Pendidikan Nasional. 
Depdiknas. (2003) Data Perkembangan SMK di Indonesia Sampai Dengan 2002. Jakarta: Ditjen Dikdasmen Dit. Dikmenjur.

Faizah, Dewi Utama. (2008) Keindahan Belajar dalam Perspektif Pedagogi. Jakarta: Cindy Grafika.

Psikoma. (2016) 15 Teknik Mengajar Guru Masa Kini. http://www.psikoma.com/mengenalteknik-guru-masa-kini/ diakses pada 25 Agustus 2017.

Sanjaya, Wina. (2011) Strategi Pembelajaran Berorientasi Standar Proses Pendidikan. Jakarta: Kencana Prenada Media.

Sardiman A.M. (2007) Interaksi dan Motivasi Belajar Mengajar. Jakarta: PT Raja Grafindo Persada.

Sudjana, Nana dan Ahmad Rivai. (2005) Media Pengajaran. Bandung: Sinar Baru Algensindo.

Susanto, Eko. (2012) 60 Games untuk Mengajar Pembuka dan Penutup Kelas. Yogyakarta: Lukita.

Uno, Hamzah B. (2008) Teori Motivasi dan Pengukurannya. Jakarta: Bumi Aksara. 